\title{
Mediterranean Diet Effects on Type 2 Diabetes Prevention, Disease Progression, and Related Mechanisms. A Review
}

\author{
Sandra Martín-Peláez ${ }^{1,2}$, Montse Fito ${ }^{3,4}$ and Olga Castaner ${ }^{3,4, *(1)}$ \\ 1 Department of Preventive Medicine and Public Health, Faculty of Medicine, University of Granada, \\ 18071 Granada, Spain; sandramartin@ugr.es \\ 2 Instituto de Investigación Biosanitaria (ibs.GRANADA), 18071 Granada, Spain \\ 3 Cardiovascular Risk and Nutrition Research Group, Hospital del Mar Medical Research Institute [IMIM], \\ 08003 Barcelona, Spain; mfito@imim.es \\ 4 Consorcio CIBER, M.P. Fisiopatologia de la Obesidad y Nutrición [CIBERObn], Instituto de Salud Carlos III \\ [ISCIII], 28029 Madrid, Spain \\ * Correspondence: ocastaner@imim.es; Tel.: +34-933-160-720; Fax: +34-933-160-796
}

Received: 10 June 2020; Accepted: 23 July 2020; Published: 27 July 2020

\begin{abstract}
The search for a quality diet has grown over the past decade. Diet is considered one of the pillars for the prevention and progression of several diseases, among them: diabetes. Type 2 diabetes (T2D) is an epidemic of western countries that increases the vulnerability of other diseases, such as cardiovascular and cancer. T2D is associated with lifestyle and diet. The traditional Mediterranean diet has proven its benefits over several cardiovascular risk factors, and specifically on diabetes. This review compiles recent published evidence on the effects of the Mediterranean diet on the incidence and progression of type 2 diabetes (T2D) and its relation with several other cardiovascular healthy diets. We will also focus on how the Mediterranean diet could play a role in T2D-related mechanisms, such as anti-inflammatory or antioxidant compounds, glucagon-like peptide agonist compounds, and changes in gut microbiota. Each component of the Mediterranean diet could be involved in processes related to diabetes homeostasis, many of them sharing common physio-pathological pathways. The importance of this diet within the set of habits of a healthy lifestyle must be emphasized.
\end{abstract}

Keywords: quality diet; primary prevention; diabetes; Mediterranean; mechanisms

\section{Background of Diabetes Epidemiology}

At present, approximately 425 million adults suffer from diabetes which caused four million deaths globally in 2017 [1]. Its prevalence in Spain is around 13.8\% in adults and it is more common in men [2]. These figures, which have reached epidemic dimensions, signify that the prevention and treatment of diabetes are currently one of the main objectives of public health policies. Moreover, by 2035 , the worldwide prevalence is estimated to affect 592 million individuals (10.1\% of the global population) [3]. Such a trend has been confirmed by the International Diabetes Federation (IDF) with its own estimation of diabetes affecting 700 million by 2045 [4]. There is, therefore, a need for preventive activities to reduce the ongoing progress of this disease and its associated complications [5]. Furthermore, patients with diabetes are considered a vulnerable population due a diversity of comorbidities. Their life expectancy is shortened by approximately six years [6], in part due to the fact that diabetes doubles the risk of cardiovascular disease $[7,8]$ and increases the risk of other diseases such as cancer $[6,9,10]$. A meta-analysis published in 2011 studied the associations between diabetes and mortality due to a number of factors including several types of cancer, such as liver, 
pancreas, ovarium, colorectal, lung, breast, and biliary [6]. In addition, diabetes is associated with cognitive impairment [11], renal or hepatic failure, mental conditions, digestive diseases, pneumonia, and others [6]. It is also linked to macro- and micro-vascular complications, including diabetic retinopathy, peripheral arteriopathy, renal diabetic disease, and diabetic neuropathy, all of which affect the patient's health and quality of life.

\section{Diabetes and Lifestyle}

The IDF has confirmed that even though the etiology of type 2 diabetes (T2D) is not completely defined, it is known that individuals with overweight, unhealthy diets, sedentarism, and a family history of diabetes have a major risk of developing this condition [12]. Unhealthy lifestyles can promote the presence of diabetes. Therefore, steps to improve them are one of the pillars of its prevention and treatment at pre-illness stages. Research into lifestyle-related behavior regarding the modification of unhealthy diets, and promotion of better dietary patterns associated with a decrease in T2D incidence [13] is therefore extremely relevant. In recent years, a considerable number of studies analyzing the benefits of diet on the incidence of diabetes have been published [13-15]. The most recent reviews and meta-analyses compare low-fat or low-carbohydrate diets, Mediterranean-type diets, and vegetarian or vegan diets [14], all of which are considered healthy dietary patterns compared to western, cafeteria-based ones or those that do not integrate any type of intervention [15]. As a novelty, recent studies have also assessed other types of interventions such as mobile applications and cooking workshops [16].

\section{Mediterranean Diet Lifestyle}

The traditional Mediterranean diet is characterized by cooking seasonal and local products, and enjoying socialization with meals. It consists of a daily abundance of vegetables, a variety of minimally processed whole grain bread, and other cereals and legumes as the staple food, nuts and seeds, fresh fruit as the typical daily dessert; sweets based on nuts, olive oil, and honey consumed only during celebratory occasions; cold pressed extra-virgin olive oil (EVOO), nuts and seeds as the principal source of fat; a low to moderate consumption of dairy products (mainly local cheese and yogurt) consumed in low amounts; a moderate consumption of fish, poultry, and eggs, a low consumption of red meat (once a week approximately), and a moderate consumption of wine, normally with meals $[17,18]$.

Regular physical activity is also part of the Mediterranean lifestyle, influenced by the climate.

\section{Mediterranean Diet and Other Healthy Diets Effects on the Incidence and Control of T2D}

We conducted a structured literature search at the United States National Library of Medicine, National Institutes of Health, and PubMed, considering publications released over the past five years which included a systematic review or meta-analysis regarding the effect of the Mediterranean diet on the incidence or better control of T2D (Table 1). The selected reviews covered more than 100,000 individuals participating in clinical trials and prospective cohort studies. Most of the reviews analyzed the association of T2D incidence with the consumption of a Mediterranean diet and sometimes compared it to other healthy diets. To assess Mediterranean diet adherence, most studies used a Mediterranean diet score. That is to say, the sum of a few items obtained from a food intake questionnaire with emphasis on the type and amount of food consumed based on the food pyramid. 
Table 1. Systematic reviews and meta-analysis of the association between Mediterranean diet and type 2 diabetes (T2D).

\begin{tabular}{|c|c|c|c|c|c|c|c|}
\hline First Author; Year & Type of Study & Type of Intervention & Population & Follow-up & Quality of the Studies & Output $[s]$ & Results \\
\hline Jannasch, F.; 2017 & $\begin{array}{l}\text { SR, MA } \\
48 \text { prospective studies: } \\
18 \text { cohorts/ACRs }\end{array}$ & MD, DASH, AHEI & $\begin{array}{l}\text { Non-diabetic healthy } \\
\quad \text { adults } \\
n \approx 1.5 \text { millions }\end{array}$ & $4.1-23$ years & $\begin{array}{c}27 \text { high quality } \\
21 \text { acceptable } \\
\text { (Scottish Intercollegiate } \\
\text { Guidelines Network checklist) }\end{array}$ & Incidence T2D & $\begin{array}{c}\text { Adherence to MD (RR quantiles: } 0.87 ; 95 \% \text { CI: } 0.82, \\
\text { 0.93), DASH (RR: } 0.81 ; 95 \% \text { CI: } 0.72,0.92) \text {, and AHEI } \\
\text { (RR: } 0.79 ; 95 \% \text { CI: } 0.69,0.90) \text { associated with a decreased } \\
\text { risk of T2D. }\end{array}$ \\
\hline Schwingshackl, L.; 2015 & $\begin{array}{c}\text { SR, MA } \\
1 \mathrm{RCT}, 8 \text { prospective } \\
\text { studies }\end{array}$ & MD & $\begin{array}{l}\text { Healthy adults or with } \\
\text { CV risk factors } \\
n=122,810\end{array}$ & $3.2-20$ years & Quality moderate & Incidence $\mathrm{T} 2 \mathrm{D}$ & $\begin{array}{l}\text { Adherence to MD high vs. low. RR: } 0.81 ; 95 \% \text { CI } 0.73 \\
0.90, \mathrm{p}<0.0001 \text { associated with a decrease in T2D } \\
\text { incidence. }\end{array}$ \\
\hline Koloverou, E.; 2014 & $\begin{array}{l}\text { SR, MA } \\
1 \text { RCT, } 9 \text { prospective } \\
\quad \text { studies }\end{array}$ & $\begin{array}{c}\mathrm{MD} \\
\text { Control diet }\end{array}$ & $\begin{array}{l}\text { Healthy adults with or } \\
\text { without } C V / T 2 D \\
n=136,846\end{array}$ & 3.5-14 years & Publication bias & Incidence $\mathrm{T} 2 \mathrm{D}$ & $\begin{array}{l}\text { High adherence to MD was associated with a } 23 \% \\
\text { decreased risk of T2D, comparing the highest vs. lowest } \\
\text { punctuation of MD RR }=0.77,95 \% \text { CI: } 0.66,0.89 .\end{array}$ \\
\hline Esposito, K.; 2014 & $\begin{array}{l}\text { MA } \\
8 \text { prospective studies, } \\
30 \text { cohorts }\end{array}$ & $\begin{array}{l}\text { MD } \\
\text { DASH }\end{array}$ & $\begin{array}{c}\text { Adults }>20 \mathrm{y} \\
n=21,372\end{array}$ & 3.2-23 years & $\begin{array}{l}\text { High heterogenicity. No } \\
\text { publication bias. } \\
\text { Quality score }>7 \text { (0 to 9) }\end{array}$ & Incidence T2D & $\begin{array}{l}\text { Healthy diet RR: } 0.80 \text { (95\% IC } 0.74-0.86) \text {. MD vs. DASH: } \\
\text { no changes in incidence of T2D. }\end{array}$ \\
\hline Esposito, K.; 2015 & $\begin{array}{c}\mathrm{SR} \\
8 \mathrm{MA}, 5 \mathrm{RCTs}\end{array}$ & $\begin{array}{c}\mathrm{MD} \\
\text { Control diet }\end{array}$ & $\begin{array}{c}\text { Adults with T2D or at } \\
\text { risk } \\
n=2087\end{array}$ & $>6$ months & $\begin{array}{l}\text { MA: moderate } \\
\text { RCTs: low }\end{array}$ & $\begin{array}{l}\text { Incidence T2D } \\
\text { Glycemic control }\end{array}$ & $\begin{array}{l}\text { MD decreases HbA1c in } 0.3-0.47 \% \text { compared to low } \\
\text { fat-diet. High MD adherence decreases T2D by } 19-23 \% \text {. }\end{array}$ \\
\hline Schwingshackl, L.; 2018 & $\begin{array}{l}\text { SR, MA } \\
56 \text { RCTs }\end{array}$ & $\begin{array}{l}\text { Low-fat diet or vegan, } \\
\text { MD, LC, paleolithic } \\
\text { hyperprotein diet }\end{array}$ & $\begin{array}{l}\text { Adults with T2D } \\
\qquad n=4937\end{array}$ & 3-48 months & Low, moderate credibility & $\begin{array}{c}\text { Glycemic control } \\
\text { HbAlc }\end{array}$ & $\begin{array}{c}\text { Compared to a low fat-diet, there is a decrease in HbA1c } \\
\text { in MD }(-0.32,95 \%-0.53,-0.11) \text { and LC }(-0.35,95 \% \\
-0.56,-0.14) \text {, and a decrease of glycemia in MD }(-0.59 \\
\text { mmol/ } 1,95 \%-1.13,-0.04) \text {. }\end{array}$ \\
\hline Emadian, A.; 2015 & $\begin{array}{c}\text { SR } \\
11 \text { RCTs }\end{array}$ & $\begin{array}{c}\text { MD, } \\
\text { Vegan diet, } \\
\text { Low glycemic index diet }\end{array}$ & $\begin{array}{l}\text { Overweight adults (IMC } \\
\geq 25 \mathrm{~kg} / \mathrm{m}^{2} \text { ) and T2D }\end{array}$ & $>6$ months & $\begin{array}{l}\text { Low medication control } \\
\text { Low adherence }\end{array}$ & $\begin{array}{c}\text { Glycemic control } \\
\text { HbAlc }\end{array}$ & $\begin{array}{l}\text { MD, vegan, and low glycemic index diets improve } \\
\text { HbAlc levels. }\end{array}$ \\
\hline Huo, R.; 2015 & $\begin{array}{l}\text { MA } \\
9 \text { RCTs }\end{array}$ & 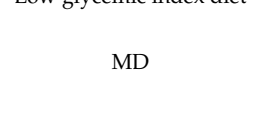 & $\begin{array}{l}\text { Adults with T2D. } \\
\qquad n=1178\end{array}$ & 1 month -4 years & $\begin{array}{l}5 \text { low quality studies and } 4 \text { high } \\
\text { quality. No publication bias for } \\
\text { HOMA (Begg's test), but for } \\
\text { HbA1c ( } p=0.001 \text {, Egger's test) }\end{array}$ & $\begin{array}{l}\text { Glycemic control } \\
\text { HbAlc, insulin, } \\
\text { HOMA }\end{array}$ & $\begin{array}{l}\text { Compared to the control group, MD decreased HbA1c } \\
\text { (median difference }-0.30 ; 95 \% \mathrm{CI}-0.46,-0.14) \text {, glucose } \\
(-0.72 \mathrm{mmol} / \mathrm{C} ; \mathrm{CI}-1.24,-0.21) \text {, and baseline insulin } \\
(-0.55 \mu \mathrm{U} / \mathrm{ml} ; \mathrm{CI}-0.81,-0.29) .\end{array}$ \\
\hline Carter, P:; 2014 & $\begin{array}{l}\text { SR, MA } \\
8 \text { RCTs }\end{array}$ & $\begin{array}{l}\text { MD, } \\
\text { Paleo diet, } \\
\text { Control diet }\end{array}$ & $\begin{array}{l}\text { Overweight and/or high } \\
\mathrm{CV} \text { risk and/or T2D } \\
n=2789\end{array}$ & 2-12 months & Few studies & $\begin{array}{l}\text { Glycemic control } \\
\text { HbA1c, insulin. }\end{array}$ & $\begin{array}{l}\text { MD decreased HbAlc compared to the control group, } \\
\text { but not to the paleo diet. None of the interventions was } \\
\text { better than the other in terms of basal glucose. }\end{array}$ \\
\hline
\end{tabular}


A major part of these studies demonstrated an association between adherence to dietary patterns and a decrease in T2D risk [13-15,19]. Regarding the analysis of incidence based on the degree of adherence to the Mediterranean diet, the studies showed a reduction of approximately $20 \%$ in T2D risk with a high score on the Mediterranean Diet Adherence Questionnaire $[14,19,20]$. Specifically, a meta-analysis involving eight cohort studies with a total of 122,810 individuals found that higher adherence to the Mediterranean diet was associated with a 19\% lower risk of suffering T2D, highlighting the long-term protective effects of the Mediterranean diet [14]. This study analyzed whether diet protection against diabetes appeared to be more marked in European populations than North American ones. It also highlighted the long-term protective effect of the Mediterranean diet, referring to follow-up studies of more than 10 years [14].

Koloverou and colleagues included in their meta-analysis one clinical trial and nine prospective studies. They observed that the T2D risk was reduced by $23 \%$ among individuals who had a maximum or minimum adherence questionnaire score in the Mediterranean diet [19].

In terms of data provided by clinical trials, the PREDIMED study, a large-scale, multicenter, controlled randomized trial, reported that a Mediterranean diet enriched with EVOO or nuts prevented diabetes, as compared to a low-fat diet, reducing the risk by $52 \%$ in the elderly with a high cardiovascular risk [20]. This beneficial effect was mainly attributed to the overall composition of the dietary pattern and not to caloric restriction, increased physical activity, or weight loss [20].

In 2017, a systematic review and meta-analysis [13] comparing different dietary patterns in a population of approximately 1.5 million participants also described that both the Mediterranean diet and other cardio-healthy diets reduced the risk of diabetes. One of these was the DASH (Dietary Approaches to Stop Hypertension Diet) [21] which aimed to control sodium intake (between 1500 milligrams (mg) and $2300 \mathrm{mg}$ of sodium/day) and promote the consumption of vegetables, fruit, and low-fat dairy products, as well as moderate amounts of whole grains, fish, poultry, and nuts. Another measure was the AHEI (Alternative Healthy Eating Index) which assessed adherence to American dietary guidelines and the food pyramid. The review focused on concordant food-based groupings and yielded results of decreasing diabetes incidence related to another meta-analysis of prospective cohort studies [22] in which both the DASH and the Mediterranean diet maintained a 20\% reduction in the risk of T2D. In this analysis, no differences were found comparing the two types of diets, as well as the follow-up time and geographical effect. The meta-analysis observed that although diets associated with the prevention of T2D may vary in composition, there are several common components such as table oils (olive oil) and whole grains, fruit, nuts, vegetables, legumes, protein-rich foods [e.g., white meat and seafood], moderate alcohol consumption, and reduced intake of red/processed meat and sweetened beverages [22].

Apart from the DASH and AHEI diets, the Mediterranean diet has also been compared to other diets, especially low-fat, low-carbohydrate, paleolithic, and vegetarian/vegan ones.

The paleolithic diet consists of eating fruit, vegetables, nuts, seeds, lean meat (especially from pasture-fed animals), fish rich in omega-3 fatty acids, and olive/walnut oils. There is, however, little scientific evidence regarding the general effects of this diet and less with respect to T2D incidence [23]. In fact, the literature about any of the alternative diets (vegan, semi-vegetarian, etc.) is not very extensive [24].

The vegetarian diet is characterized by the consumption of whole plant foods and encompasses a variety of diets that include one or another group of foods. The most restrictive is veganism which consumes no animal-derived products; lacto-ovo-vegetarians do not eat meat, but regularly consume milk, dairy products, and eggs; fish-vegetarians consume fish, milk, dairy products, and eggs; and semi-vegetarians consume meat and meat products minimally but regularly.

It has been observed that vegetarian diets are inversely associated with the risk of developing T2D regardless of the positive association of meat consumption with its development. With respect to follow-up studies, a publication from an Adventist society referred to a $74 \%$ reduction in diabetes incidence from a meat-based diet in a 17-year follow-up [25]. Another study in a Buddhist society found 
that adherence to a vegetarian diet was associated with a 35\% lower risk of developing diabetes [26]. In addition, the Rotterdam study [27] showed that a vegetarian-based diet adapted from Satija and colleagues reduced the risk of diabetes $(\sim 18 \%)$ and pre-diabetes $(\sim 11 \%)$ after a follow-up of four to seven years.

Returning to the Mediterranean diet, there is a considerable number of publications regarding its specific components, some of which have been individually reported to reduce diabetes incidence. For instance, a higher intake of olive oil was associated with a lower risk of diabetes in a cohort of women during a 22-year follow-up [28]. The authors explained that substituting other types of seasonings (e.g., margarine, butter, and mayonnaise) for olive oil was inversely associated with the onset of the disease [28].

\section{Benefits of the Mediterranean Diet on Glycemic Control}

Over the years, a number of diets have been proposed as being suitable for diabetic patients without any clear conclusions [29,30]. According to the recommendations of the American Diabetes Association (ADA), nutritional therapy for adults with diabetes should focus on promoting healthy eating patterns based on key nutrients, varied, selected, and integrated in the right amount, aiming to maintain a healthy weight, and reach optimum levels of glycosylated hemoglobin (HbA1c), blood pressure, and lipid profile. To achieve this, the ADA emphasizes that cultural preferences should be considered, as well as the areas where patients live, access to recommended foods, and a willingness to change [31]. It refers to maintaining the pleasure of eating and providing the necessary tools to empower patients to establish healthy eating patterns themselves, rather than talking about unique foods or micro/macronutrients. In this context, a healthy dietary pattern such as the traditional Mediterranean one could be the key to obtaining a proper control of diabetes [31,32].

Articles published in indexed journals rely on different parameters to analyze improvement in diabetes control. They are generally based on enhancements in HbA1c levels, and, in some cases, on basal glycemia. A systematic review of eight meta-analyses and five randomized controlled trials examined the effect of the Mediterranean diet on the treatment of diabetes and prediabetic states [33]. It indicated that in diabetic patients, adherence to the Mediterranean diet was associated with lower $\mathrm{HbA} 1 \mathrm{c}$ levels and a better profile of cardiovascular risk factors, compared to control diets, mainly with a low-fat diet content [33].

The success of the Mediterranean diet in reducing $\mathrm{HbA1c}$ values is clear; nevertheless, the degree to which it is compared depends on the diet. For example, if we compare it with a low-fat one [14,22] or a control group [34], it seems that the Mediterranean diet reduces $\mathrm{HbA1c}$ by 0.32 to 0.53 percentage units. In contrast, when compared to other diets, such as the vegan or paleolithic ones, two meta-analyses did not show an improvement in the reduction of $\mathrm{HbA1c}[14,30]$. On the other hand, in patients with newly diagnosed diabetes, another clinical trial described better glycemic control in a group adhering to a Mediterranean diet with energy restriction compared to those that followed a low-fat diet [34].

Good control of glycemia can reduce the risk of diabetes complications in the short-, medium-, and long-term [35]. The ATTICA study described that adherence to the Mediterranean diet was linked to improved fasting glucose homeostasis, insulin levels, and a better insulin resistance index (HOMA) in both normoglycemic individuals and diabetic participants. Those who had a high score of Mediterranean diet adherence presented 15\% lowered basal glucose and insulin, and a $27 \%$ increased HOMA index [36]. In this regard, in the 722 PREDIMED participants at high cardiovascular risk, a decrease of 0.39 and $0.30 \mathrm{mmol} / \mathrm{L}$ in fasting glycemia was observed in the oil-enriched and nut-enriched diet groups, respectively, with respect to the control in the absence of weight loss after three months of intervention [37]. In the same line, two randomized trials assessed the beneficial effect of the Mediterranean diet on glycemia. One trial with 279 participants in a six-month intervention with a Mediterranean diet pattern reported a reduction of 0.4 percentage units in $\mathrm{HbA} 1 \mathrm{c}$, compared to the control [38]. The other with 322 participants randomized to three different interventions (low carbohydrate and without calorie restriction; Mediterranean hypocaloric; low fat and hypocaloric) 
found concordant results. In a subgroup of 36 individuals with diabetes, there was also a reduction of $\mathrm{HbA} 1 \mathrm{c}$ of $0.4 \pm 1.3 \%$ in the low-fat diet group, $0.5 \pm 1.1 \%$ in the Mediterranean diet group, and $0.9 \pm 0.8 \%$ in the low-carb diet group. Finally, in a one-year randomized trial of 259 patients with T2D, three diets were compared, low-carbohydrate Mediterranean, traditional Mediterranean, and an ADA-proposed one [39]. The mean weight loss was $10.1,7.4$, and $7.7 \mathrm{~kg}$, respectively, and reductions in HbA1c were described in participants assigned to the low-carbohydrate Mediterranean diet and the traditional Mediterranean one $(0.4 \%$ and $0.2 \%$ reductions, respectively) versus the ADA diet [39]. Despite the promising results of these studies, glycemia levels rise in the course of T2D [40,41]. This implies the need for a sequential increase in therapies [41]. In this regard, in a randomized trial of 215 patients with newly diagnosed T2D who were assigned to a low-carbohydrate Mediterranean-style diet, there was a delay in the need for new hypoglycemic drugs with respect to a low-fat diet, yet $44 \%$ to $70 \%$ of participants required treatment after a four-year follow-up [42]. It should be noted that participants assigned to the Mediterranean-style diet lost more weight than those on the low-fat one [42].

Apart from the general Mediterranean diet pattern, the scientific community has investigated the effect of certain specific components such as olive oil. In a randomized, cross-over trial it was observed that regular and moderate daily consumption $(25 \mathrm{~mL} /$ day) of virgin olive oil (phenolic compounds: $577 \mathrm{mg} / \mathrm{kg}$ ) for eight weeks in overweight and T2D patients lowered fasting plasma glucose and HbA1c [43]. Another study examined how monounsaturated fatty acids, the main component of olive oil, were associated with a lower concentration of fasting plasma glucose in 4903 Italian men and women aged 20 to 59 years [44,45]. In a cross-sectional study in Spain (PIZARRA), insulin resistance was found to be lower in individuals who consumed olive oil compared to those who consumed sunflower oil or a combination [3].

With regard to other diets, we find that there is very little scientific evidence regarding the paleolithic diet effect on the treatment and control of diabetes. Few clinical trials have been published and the sample sizes are limited (14-32 individuals). It seems that in a clinical trial where T2D participants underwent 12 weeks of paleolithic diet compared to a regular one, there was an improvement in diabetes management; nevertheless, this should be corroborated with larger sample studies [23].

The same goes for publications regarding the effect of vegetarian diets on the treatment of established diabetes. They refer to studies that are quite small when comparing a vegetarian diet in general, or some subtype with the usual diet prescribed for diabetic individuals. A number of authors have differentiated between these types of diets while others have grouped them. In general, however, they are considered beneficial for both the prevention and control of diabetes [46-48].

In brief, there is good evidence that adherence to the Mediterranean diet seems to have a protective role in glycemic control, reducing $\mathrm{HbA} 1 \mathrm{c}$, and lowering fasting levels in addition to decreased insulin resistance and mortality. Sleiman et al. suggest in their review that reducing oxidative stress, inflammation, and insulin resistance are all possible mechanisms by which the Mediterranean diet pauses as a protective dietary pattern [49].

\section{Mechanisms Involved in Mediterranean Diet Effects on T2D}

The current knowledge about the mechanisms developing diabetes indicates that they are varied and interconnected. The main physio-pathological process of T2D is the state of sustained hyperglycemia caused by pancreatic $\beta$-cells impaired insulin secretion and/or cell insulin resistance (IR). This signifies that either insulin is not generated in adequate amounts, or it is unable to get glucose into the cells, or both. In any case, the consequences are the dysregulation of carbohydrate, lipid and protein metabolism, and eventually macro- and micro-vascular complications [50]. Proper insulin secretion by $\beta$-cells can be influenced by several factors in addition to genetic abnormalities or aging [51]. In this regard, lipotoxicity [52], glucotoxicity [53], reactive oxygen stress [54], activation of inflammatory pathways [52], IR leading to $\beta$-cell stress [52,55], and/or the decrease in incretin effect (GPL1 and GIP) on $\beta$-cells, amongst others, contribute to $\beta$-cell impaired insulin secretion. How cells become resistant to insulin is a major area of research. Currently, it is known that there exist 
both intrinsic cellular pathways and extrinsic mechanisms. The first include cellular mitochondrial dysfunction, oxidative stress, and endoplasmic reticulum stress. The second comprise adipocyte and fatty acid level alterations and inflammation [56].

\subsection{Mediterranean Diet and T2D}

Although T2D is a multifactorial disease which involves genetic and environmental factors, healthy lifestyles, including proper diet, are considered key factors in its development [57]. We will therefore focus on how the Mediterranean diet could play a role in T2D-related mechanisms.

As previously stated, many studies have found a positive effect of the Mediterranean diet on T2D. In order to elucidate which mechanisms are behind these effects it is necessary to examine its characteristics.

The Mediterranean diet is able to reduce central obesity and, in turn, reduce obesity-related chronic diseases [58] such as T2D. In fact, this diet is superior to low-fat ones for long-term weight loss [59]. In addition, it is associated with a more significant improvement of IR in obese individuals when compared to other low-energy dietary approaches. Therefore, the composition of the Mediterranean diet, rather than the calories provided, must play a role on T2D positive effects. Moreover, while the individual effects of the distinct dietary components may be too small to be detected, their additive impact may be large enough to be discerned [18].

\subsection{Mechanisms Based on Anti-inflammatory/Antioxidant Compounds}

The effects exerted by the Mediterranean diet on T2D could probably be attributed to its anti-inflammatory/antioxidant compounds. It is known that individuals with diabetes have significantly lower levels of ascorbic acid, $\beta$-carotene, and $\alpha$-tocopherol/cholesterol ratio than non-diabetic ones [60]. The consumption of this diet raises plasma levels of diet-derived plasma antioxidants [61], increases both the plasma ferric reducing antioxidant potential (FRAP) and the total radical-trapping antioxidant parameter (TRAP) [62], lowers c-reactive protein (CRP) levels [63], and prevents the acute hyperglycemia effect on inflammation, oxidative stress, and endothelial function.

Of the vast variety of anti-inflammatory/antioxidant compounds present in the Mediterranean diet, the phenolic compounds (PC) are the most ubiquitous, particularly flavonoids. The flavonoid quercetin is able to activate the insulin-independent adenosine monophosphate-activated protein kinase (AMPK) pathway of skeletal muscle cells, slowing the oxygen consumption of adenosine diphosphate in isolated mitochondria [64]. In addition, quercetin can enhance the uptake of glucose in skeletal myocytes through an AMPK-dependent up-regulation of glucose transporter GLUT-4 under oxidative stress conditions [65].

In addition to olive oil, PC are found in fruit, vegetables, legumes, and cereals. The major PC in olive oil are oleuropein, hydroxytyrosol, and tyrosol, and they are able to exert antioxidant and anti-inflammatory activities [66]. In this regard, it has been observed that the PC in EVOO improve oxidative stress by decreasing the activation of pro-inflammatory mediators and increasing bioavailability of nitric oxide, which enhances the vasodilator-dependent response of endothelium [67].

Apart from PC, EVOO is rich in poly-unsaturated fatty acids (PUFA) which ameliorate the adipose tissue inflammatory responses, providing beneficial effects on insulin sensitivity [68]. In obesity, dysfunctional adipose tissue overproduces pro-inflammatory cytokines and chemokines, such as tumor necrosis factor alfa, interleukin-6, and resistin, which activate intracellular pathways that trigger IR in insulin-target tissues. Thus, the anti-inflammatory potential of PUFA may indirectly improve peripheral insulin responsiveness, reducing the risk of glyco-metabolic alterations in patients with IR [68]. In this regard, the monounsaturated fatty acids (MUFA), the main fat of EVOO (especially oleic acid) and also present in other components of the Mediterranean diet, are thought to counteract the effect promoted by saturated fatty acids (SFA) which decrease the insulin sensitivity (IS) of peripheral tissues $[69,70]$. Moreover, IS and $\beta$-cell function progressively improve in the postprandial state as the ratio of MUFA to SFA in the diet increases [71]. Besides the beneficial effects of EVOO PUFA on 
inflammation and oxidation, favorable effects can be observed only at a total fat intake below $37 \%$ of energy, since a higher fat intake increases the risk of IR irrespective of quality [72].

EVOO also contains other potent antioxidants such as $\alpha$-tocopherol, carotenoids, and phytosterols [73]. Furthermore, it has been shown that $50 \mathrm{~g}$ of newly pressed EVOO contains up to $9 \mathrm{mg}$ of olechantal, a phytochemical with ibuprofen-like COX-inhibitory activity [74]. The Mediterranean diet is also a rich source of omega- 3 fatty acids whose intake is inversely correlated with circulating inflammatory markers and triglyceride levels. The anti-inflammatory effects of omega-3 fatty acids seem to be mediated by binding to the G-protein-coupled receptor 120 and inhibition of NLRP3 inflammasome activity $[75,76]$.

\subsection{Mechanisms Based on Glucagon-like Peptide Agonist Compounds}

The glucagon-like peptide (GLP-1) is an incretin hormone which promotes insulin generation and secretion, and inhibits gastric emptying and glucagon secretion, thus having a favorable effect on the management of T2D [77]. GLP-1 has been shown to improve endothelial function in diabetes [78,79] possibly by increasing the antioxidant defenses of the endothelium [80] and decreasing oxidative stress generation [79]. In addition, it may influence satiety at the central nervous system level, attenuating appetite sensations and, consequently, the amount of food consumed so that energy intake does not exceed expenditure. It has been suggested that hyperglycemia induces GLP-1 resistance, mainly through the generation of oxidative stress [79]. Eventually, $\beta$-cell resistance to GLP- 1 contributes to progressive failure in the function of $\beta$-cells. The Mediterranean diet improves the action of GLP-1 action. In particular, PUFA from EVOO may have shown to bind and stimulate G-protein-coupled receptors such as GPR120, leading to an increased secretion of GLP-1 from enteroendocrine L-cells [80]. By stimulating insulin release from pancreatic $\beta$-cells, with immediate consequences of increased glucose uptake from skeletal muscles, raised GLP-1 levels may in turn limit postprandial hyperglycemia [81].

\subsection{Mechanisms Based on Branched Chain Aminoacid Management}

Branched chain amino acids (BCAA) play critical roles in the regulation of energy homeostasis, nutrition metabolism, gut health, immunity, and disease. Moreover, current evidence supports BCAA, and their derivatives, as potential biomarkers of pathologies such as IR, T2D, cancer, and cardiovascular diseases all of which are closely associated with BCAA catabolism and balance [82]. High levels of serum BCAA (valine, leucine, isoleucine) are positively associated with increased T2D risk [83]. Elevated levels of BCAAs are known to activate mTOR complex 1 (mTORC1) which leads to IR through the phosphorylation of insulin receptor substrate 1 (IRS-1) [84,85]. BCAA also stimulate the activation of the redox-sensitive transcription factor NF- $\mathrm{kB}$, resulting in the release of pro-inflammatory molecules (IL-6, TNF- $\alpha$, intracellular adhesion molecule-1, CD40L) and the migration of peripheral mononuclear blood cells [86]. These pro-inflammatory changes could contribute to the development of IR. In a large-scale randomized trial, the regular consumption of EVOO has been reported to decrease the levels of plasma BCAA [87].

\subsection{Mechanisms Based on Changes in Gut Microbiota}

Gut microbiota is composed mainly of bacteria, although it also includes commensal populations of fungi, viruses, archaea, and protists. Regarding bacteria, there are four main phyla living in the gut microbiota (Firmicutes, Bacteroidetes, Actinobacteria, and Proteobateria) each of which contain a vast variety of bacterial strains. When living in harmony, these bacteria exert fundamental roles in human physiology and metabolism. In contrast, gut microbiota imbalance, or dysbiosis, can negatively affect human homeostasis and is the key in the pathogenesis of a variety of illnesses including T2D [88,89]. For example, T2D has been related to decreases in Firmicutes [90] and other butyrate-producing species [91,92], and to increases in opportunistic pathogens [93] and sulfate-reducing bacteria [91,92]. Moreover, increased levels of BCAA serum from IR-individuals correlate with a gut microbiome with enriched biosynthetic potential for BCAA. Prevotella copri and Bacteroides vulgatus have been identified 
as the main species driving the association between biosynthesis of BCAA and IR [94]. Dysbiosis can lead to increased gut permeability and intestinal Toll-like receptor (TLR) activations through microbial components and pathogen-associated molecular patterns (PAMPs) including lipopolysaccharide (LPS), flagellin, lipoteichoic acid, and peptidoglycan resulting in the production of inflammatory cytokines [95]. In fact, bacteria lipopolysaccharide levels are higher in diabetic compared to non-diabetic patients [96]. These alterations also have consequences on the microbial products generated by bacterial metabolism which, in turn, have an impact on T2D. For example, a reduction in the excretion of the microbial metabolites hippurate, PAG and p-cresol, as well as trigonelline and 3-hydroxymandelate, has been observed in T2D patients [97].

Diet content and quantity play a major role in shaping the human microbiota composition and function [98,99]. Complex interactions between nutrients and microorganisms dictate beneficial or detrimental outcomes to host health [100]. In this regard, the Mediterranean diet has been observed to positively influence gut microbiota. For example, obese men consuming this diet for one year obtained a protective effect on the development of T2D through different specific changes in the gut microbiota [101]. The Mediterranean diet is rich in dietary fiber and complex carbohydrates. In this regard, the main gut microbiota microbial products, the short chain fatty acids (SCFA), are generated by fermentation of dietary fibers. SCFA (acetate, butyrate, and propionate) exert many relevant functions for the host. Regarding T2D, SCFA contribute to the regulation of glucose and lipid metabolism by the activation of SCFA receptors in the liver, adipose tissue, brain, and pancreas [101]. In addition, SCFA can stimulate GLP-1 and GLP-2 secretion, thereby enhancing insulin sensitivity, pancreatic $\beta$-cell proliferation [102], and satiety [103]. In this regard, in T2D patients, a deficiency in SCFA [104] has been observed, particularly a reduction in butyrate [105]. The Mediterranean diet can stimulate the production of SCFA by gut microbiota due to its elevated content in dietary fibers. Other metabolites with potent anti-inflammatory and antioxidant properties generated by gut microbiota metabolism, such as Indole-2 propionic acid (IPA), have been reported to increase after four days of ingestion of the Mediterranean diet compared to four days of fast food [106].

\section{Conclusions}

To sum up, there is consistent evidence regarding the inverse association between the adherence to a Mediterranean diet and incidence of T2D. In addition, some evidence of the association between DASH diet and T2D exists. Furthermore, the Mediterranean diet has been shown to decrease HbA1c levels compared to a control group (such as low-fat diet and low-carbohydrate diet). On the other hand, vegan and low glycemic index diets also improve $\mathrm{HbA1c}$ levels.

To sum up, each component of the Mediterranean diet could be involved in processes related to diabetes homeostasis, many of them sharing common physio-pathological pathways. The Mediterranean diet adherence could play a role on T2D-related mechanisms, such as anti-inflammatory/antioxidant actions, glucagon-like peptide agonist compounds, and changes in gut microbiota. Overall, single actions from different nutrients and derivative metabolites could be enhanced by interactions and synergies that make the Mediterranean diet an invaluable tool in the primary and secondary prevention of diabetes. The importance of this diet within the set of habits of a healthy lifestyle must be emphasized.

Author Contributions: M.F. conceived the idea; S.M.-P. and O.C. wrote the original draft; M.F. substantively revised the work. All authors have read and agreed to the published version of the manuscript.

Funding: This research was supported by grants of the Instituto de Salud Carlos III (ISCIII-FEDER) PI18/00020 and JR17/00022.

Acknowledgments: Authors wish to thank Stephanie Lonsdale for her help in editing the text. CIBER de Fisiopatología de la Obesidad y Nutrición is an initiative of the Instituto de Salud Carlos III, Madrid, Spain, and financed by the European Regional Development Fund.

Conflicts of Interest: The authors declare that they have no conflict of interest. 


\section{Abbreviations}

$\begin{array}{ll}\text { MD } & \text { Mediterranean diet } \\ \text { DASH } & \text { Dietary Approach to Stop Hypertension } \\ \text { SR } & \text { Systematic review } \\ \text { MA } & \text { Meta-analysis } \\ \text { RCTs } & \text { Randomized clinical trials } \\ \text { T2D } & \text { Type 2 diabetes } \\ \text { AHEI } & \text { Alternative healthy eating index } \\ \text { CV } & \text { Cardiovascular } \\ \text { LC } & \text { Low-carbohydrate diet } \\ \text { HbA1c } & \text { Glycosylated hemoglobin } \\ \text { HOMA } & \text { Insulin resistance index }\end{array}$

\section{References}

1. International Diabetes Federation. IDF Diabetes Atlas, 8th ed.; International Diabetes Federation: Brussels, Belgium, 2017.

2. Valdés, S.; García-Torres, F.; Maldonado-Araque, C.; Godayc, A.; Calle-Pascuald, A.; Soriguerab, F.; Castañoae, L.; Cataláaf, M.; Gomisag, R.; Rojo-Martíneza, G.; et al. Prevalence of obesity, diabetes and other cardiovascular risk factors in Andalusia [southern Spain]. Comparison with national prevalence data. The Di@bet.es study. Rev. Esp. Cardiol. 2014, 67, 442-448. [CrossRef] [PubMed]

3. Soriguer, F.; Goday, A.; Bosch-Comas, A.; Bordiú, E.; Calle-Pascual, A.; Carmena, R.; Casamitjana, R.; Castaño, L.; Castell, C.; Catalá, M.; et al. Prevalence of diabetes mellitus and impaired glucose regulation in Spain: The Di@bet.es Study. Diabetologia 2012, 55, 88-93. [CrossRef]

4. Saeedi, P.; Petersohn, I.; Salpea, P.; Malanda, B.; Karuranga, S.; Unwin, N.; Colagiuri, S.; Guariguata, L.; Motala, A.A.; Ogurtsova, K.; et al. Global and regional diabetes prevalence estimates for 2019 and projections for 2030 and 2045: Results from the International Diabetes Federation Diabetes Atlas, 9(th) edition. Diabetes Res. Clin. Pract. 2019, 157, 107843. [CrossRef] [PubMed]

5. Baena-Díez, J.M.; Peñafiel, J.; Subirana, I.; Ramos, R.; Elosua, R.; Marín-Ibañez, A.; Guembe, M.J.; Rigo, F.; Tormo-Díaz, M.J.; Moreno-Iribas, C.; et al. Risk of Cause-Specific Death in Individuals with Diabetes: A Competing Risks Analysis. Diabetes Care 2016, 39, 1987-1995. [CrossRef] [PubMed]

6. Seshasai, S.R.K.; Kaptoge, S.; Thompson, A.; Di Angelantonio, E.; Gao, P.; Sarwar, N.; Whincup, P.H.; Mukamal, K.; Gillum, R.F.; Holme, I.; et al. Emerging Risk Factors Collaboration. Diabetes mellitus, fasting glucose, and risk of cause-specific death. N. Engl. J. Med. 2011, 364, 829-8415.

7. Sarwar, N.; Gao, P.; Seshasai, S.R.; Gobin, R.; Kaptoge, S.; Di Angelantonio, D.; Ingelsson, E.; Lawlor, D.A.; Selvin, E.; Stampfer, M.; et al. Emerging Risk Factors Collaboration. Diabetes mellitus, fasting blood glucose concentration, and risk of vascular disease: A collaborative meta-analysis of 102 prospective studies. Lancet 2010, 375, 2215-2222.

8. Tancredi, M.; Rosengren, A.; Svensson, A.M.; Kosiborod, M.; Pivodic, A.; Gudbjörnsdottir, S.; Wedel, H.; Clements, M.; Dahlqvist, S.; Lind, M. Excess Mortality among Persons with Type 2 Diabetes. N. Engl. J. Med. 2015, 373, 1720-17326. [CrossRef]

9. Atchison, E.A.; Gridley, G.; Carreon, J.D.; Leitzmann, M.F.; McGlynn, K.A. Risk of cancer in a large cohort of U.S. veterans with diabetes. Int. J. Cancer 2011, 128, 635-643. [CrossRef]

10. Tseng, C.H.; Tseng, F.H. Gastric cancer: Diabetes and gastric cancer: The potential links. World J. Gastroenterol. 2014, 20, 1701-1711. [CrossRef]

11. Farooqui, A.A.; Farooqui, T. Effect of MediterraneanDiet Components on Type 2 Diabetes and Metabolic Syndrome. In Role of the Mediterranean Diet in the Brain and Neurodegenerative Diseases; Academic Press: Cambridge, MA, USA, 2018; Chapter 13; pp. 209-222.

12. International Diabetes Federation. 2003. Available online: http://www.idf.org/diabetesatlas (accessed on 22 July 2020).

13. Jannasch, F.; Kröger, J.; Schulze, M.B. Dietary Patterns and Type 2 Diabetes: A Systematic Literature Review and Meta-Analysis of Prospective Studies. J. Nutr. 2017, 147, 1174-1182. [CrossRef] 
14. Schwingshackl, L.; Missbach, B.; König, J.; Hoffmann, G. Adherence to a Mediterraneandiet and risk of diabetes: A systematic review and meta-analysis. Public Health Nutr. 2015, 18, 1292-1299. [CrossRef] [PubMed]

15. Bloomfield, H.E.; Koeller, E.; Greer, N.; MacDonald, R.; Kane, R.; Wilt, T.J. Effects on Health Outcomes of a MediterraneanDiet With No Restriction on Fat Intake: A Systematic Review and Meta-analysis. Ann. Intern. Med. 2016, 165, 491-500. [CrossRef] [PubMed]

16. Alonso-Domínguez, R.; Gómez-Marcos, M.A.; Patino-Alonso, M.C.; Sánchez-Aguadero, N.; Agudo-Conde, C.; Castaño-Sánchez, C.; García-Ortiz, L.; Recio-Rodríguez, J.I. Effectiveness of a multifactorial intervention based on an application for smartphones, heart-healthy walks and a nutritional workshop in patients with type 2 diabetes mellitus in primary care [EMID]: Study protocol for a randomised controlled trial. BMJ Open 2017, 7, e016191. [CrossRef] [PubMed]

17. Fundación dieta mediterránea. Available online: https://dietamediterranea.com (accessed on 22 July 2020).

18. Tosti, V.; Bertozzi, B.; Fontana, L. Health Benefits of the MediterraneanDiet: Metabolic and Molecular Mechanisms. J. Gerontol. Ser. A 2018, 73, 318-326. [CrossRef] [PubMed]

19. Koloverou, E.; Esposito, K.; Giugliano, D.; Panagiotakos, D. The effect of Mediterraneandiet on the development of type 2 diabetes mellitus: A meta-analysis of 10 prospective studies and 136,846 participants. Metabolism 2014, 63, 903-911. [CrossRef] [PubMed]

20. Salas-Salvadó, J.; Bulló, M.; Estruch, R.; Ros, E.; Covas, M.-I.; Ibarrola-Jurado, N.; Corella, D.; Arós, F.; Gómez-Gracia, E.; Ruiz-Gutiérrez, V.; et al. Prevention of diabetes with MediterraneanDiets: A subgroup analysis of a randomized trial. Ann. Intern. Med. 2014, 160, 1-10.

21. DASH diet: Healthy eating to lower your blood pressure. Available online: https://www.mayoclinic.org/eses/healthy-lifestyle/nutrition-and-healthy-eating/in-depth/dash-diet/art-20048456 (accessed on 22 July 2020).

22. Esposito, K.; Chiodini, P.; Maiorino, M.I.; Bellastella, G.; Panagiotakos, D.; Giugliano, D. Which diet for prevention of type 2 diabetes? A meta-analysis of prospective studies. Endocrine 2014, 47, 107-116. [CrossRef]

23. Masharani, U.; Sherchan, P.; Schloetter, M.; Stratford, S.; Xiao, A.; Sebastian, A.; Kennedy, M.N.; Frassetto, L. Metabolic and physiologic effects from consuming a hunter-gatherer [Paleolithic]-type diet in type 2 diabetes. Eur. J. Clin. Nutr. 2015, 69, 944-948. [CrossRef]

24. Olfert, M.D.; Wattick, R.A. Vegetarian Diets and the Risk of Diabetes. Curr. Diabetes Rep. 2018, $18,101$. [CrossRef]

25. Vang, A.; Singh, P.N.; Lee, J.W.; Haddad, E.H.; Brinegar, C.H. Meats, processed meats, obesity, weight gain and occurrence of diabetes among adults: Findings from adventist health studies. Ann. Nutr. Metab. 2008, 52, 9604. [CrossRef]

26. Chiu, T.H.T.; Pan, W.-H.; Lin, M.-N.; Lin, C.-L. Vegetarian diet, change in dietary patterns, and diabetes risk: A prospective study. Nutr. Diabetes 2018, 8, 12. [CrossRef]

27. Chen, Z.; Zuurmond, M.G.; Van der Schaft, N.; Nano, J.; Wijnhoven, H.A.H.; Ikram, M.A.; Franco, O.H.; Voortman, T. Plant versus animal based diets and insulin resistance, prediabetes and type 2 diabetes: The Rotterdam Study. Eur. J. Epidemiol. 2018, 33, 883-893. [CrossRef] [PubMed]

28. Guasch-Ferré, M.; Hruby, A.; Salas-Salvadó, J.; Martínez-González, M.A.; Sun, Q.; Willett, W.C.; Hu, F.B. Olive oil consumption and risk of type 2 diabetes in US women. Am. J. Clin. Nutr. 2015, 102, 479-486. [CrossRef] [PubMed]

29. Emadian, A.; Andrews, R.C.; England, C.Y.; Wallace, V.; Thompson, J.L. The effect of macronutrients on glycaemic control: A systematic review of dietary randomised controlled trials in overweight and obese adults with type 2 diabetes in which there was no difference in weight loss between treatment groups. Br. J. Nutr. 2015, 114, 1656-1666. [CrossRef]

30. Carter, P.; Achana, F.; Troughton, J.; Gray, L.J.; Khunti, K.; Davies, M.J. AM editerraneandiet improves HbA1c but not fasting blood glucose compared to alternative dietary strategies: A network meta-analysis. J. Hum. Nutr. Diet. 2014, 27, 280-297. [CrossRef]

31. American Diabetes Association. Lifestyle Management: Standards of Medical Care in Diabetes-2018. Diabetes Care 2018, 41, S38-S50. [CrossRef] [PubMed]

32. Evert, A.B.; Boucher, J.L.; Cypress, M.; Dunbar, S.A.; Franz, M.J.; Mayer-Davis, E.J.; Neumiller, J.J.; Nwankwo, R.; Verdi, C.L.; Urbanski, P.; et al. Nutrition therapy recommendations for the management of adults with diabetes. Diabetes Care 2014, 37, S120-S143. [CrossRef] 
33. Esposito, K.; Maiorino, M.I.; Bellastella, G.; Chiodini, P.; Panagiotakos, D.; Giugliano, D. A journey into a Mediterraneandiet and type 2 diabetes: A systematic review with meta-analyses. BMJ Open 2015, 5. [CrossRef] [PubMed]

34. Huo, R.; Du, T.; Xu, Y.; Xu, W.; Chen, X.; Sun, K.; Yu, X. Effects of Mediterranean-style diet on glycemic control, weight loss and cardiovascular risk factors among type 2 diabetes individuals: A meta-analysis. Eur. J. Clin. Nutr. 2015, 69, 1200-1208. [CrossRef] [PubMed]

35. UK Prospective Diabetes Study [UKPDS] Group. Intensive blood-glucose control with sulphonylureas or insulin compared with conventional treatment and risk of complications in patients with type 2 diabetes [UKPDS 33]. Lancet 1998, 352, 837-853. [CrossRef]

36. Panagiotakos, D.B.; Tzima, N.; Pitsavos, C.; Chrysohoou, C.; Zampelas, A.; Toussoulis, D.; Stefanadis, C. The association between adherence to the Mediterraneandiet and fasting indices of glucose homoeostasis: The Attica study. J. Am. Coll. Nutr. 2007, 26, 32-38. [CrossRef] [PubMed]

37. Estruch, R.; Martínez-González, M.A.; Corella, D.; Salas-Salvadó, J.; Ruiz-Gutiérrez, V.; Covas, M.I.; Fiol, M.; Gómez-Gracia, E.; López-Sabater, M.C.; Vinyoles, E.; et al. Effects of a Mediterranean-style diet on cardiovascular risk factors: A randomized trial. Ann. Intern. Med. 2006, 145, 1-11. [CrossRef] [PubMed]

38. Toobert, D.J.; Glasgow, R.E.; Strycker, L.A.; Barrera, M., Jr.; Radcliffe, J.L.; Wander, R.C.; Bagdade, J.D. Biologic and quality-of-life outcomes from the MediterraneanLifestyle Program: A randomized clinical trial. Diabetes Care 2003, 26, 2288-2293. [CrossRef] [PubMed]

39. Elhayany, A.; Lustman, A.; Abel, R.; Attal-Singer, J.; Vinker, S. A low carbohydrate Mediterraneandiet improves cardiovascular risk factors and diabetes control among overweight patients with type 2 diabetes mellitus: A 1-year prospective randomized intervention study. Diabetes Obes. Metab. 2010, 12, 204-209. [CrossRef]

40. Kahn, S.E.; Haffner, S.M.; Heise, M.A.; Kravitz, B.G.; Lachin, J.M.; O’Neill, M.O.; Zinman, B.; Herman, W.H.; Holman, R.R.; Jones, N.P.; et al. Glycemic durability of rosiglitazone, metformin, or glyburide monotherapy. N. Engl. J. Med. 2006, 355, 2427-2443. [CrossRef]

41. Turner, R.C.; Cull, C.A.; Frighi, V.; Holman, R.R.; UK Prospective Diabetes Study [UKPDS] Group. Glycemic control with diet, sulfonylurea, metformin, or insulin in patients with type 2 diabetes mellitus: Progressive requirement for multiple therapies [UKPDS 49]. JAMA 1999, 281, 2005-2012. [CrossRef]

42. Esposito, K.; Maiorino, M.I.; Ciotola, M.; Esposito, K.; Maiorino, M.I.; Ciotola, M.; Di Palo, C.; Scognamiglio, P.; Gicchino, M.; Petrizzo, M.; et al. Effects of a Mediterranean-style diet on the need for antihyperglucemic drug therapy in patients with newly diagnosed type 2 diabetes: A randomized trial. Ann. Intern. Med. 2009, 151, 306-314. [CrossRef]

43. Santangelo, C.; Filesi, V.R.; Scazzocchio, B.; Filardi, T.; Fogliano, V.; D’Archivio, M.; Giovannini, C.; Lenzi, A.; Morano, S.; Masella, R. Consumption of extra-virgin olive oil rich in phenolic compounds improves metabolic control in patients with type 2 diabetes mellitus: A possible involvement of reduced levels of circulating visfatin. J. Endocrinol. Investig. 2016, 39, 1295-1301. [CrossRef]

44. Tierney, A.C.; Roche, H.M. The potential role of olive oil-derived MUFA in insulin sensitivity. Mol. Nutr. Food Res. 2007, 51, 1235-1248. [CrossRef]

45. Trevisan, M.; Krogh, V.; Freudenheim, J.; Blake, A.; Muti, P.; Panico, S.; Farinaro, E.; Mancini, M.; Menotti, A.; Ricci, G. Consumption of olive oil, butter and vegetable oils and coronary heart disease risk factors. The Research Group ATS-RF2 of the Italian National Research Council. J. Am. Med. Assoc. 1990, 26, 688-692. [CrossRef]

46. Zhao, Z.; Li, S.; Liu, G.; Yan, F.; Ma, X.; Huang, X.Z.; Tian, H. Body iron stores and heme-iron intake in relation to risk of type 2 diabetes: A systematic review and meta-analysis. PLoS ONE 2012, 7, e41641. [CrossRef] [PubMed]

47. Lee, Y.; Park, K. Adherence to a Vegetarian Diet and Diabetes Risk: A Systematic Review and Meta-Analysis of Observational Studies. Nutrients 2017, 9, 603.

48. Utami, D.B.; Findyartini, A. Plant-based Diet for HbA1c Reduction in Type 2 Diabetes Mellitus: An Evidence-based Case Report. Acta Med. Indones. 2018, 50, 260-267. [PubMed]

49. Sleiman, D.; Al-Badri, M.R.; Azar, S.T. Effect of Mediterraneandiet in diabetes control and cardiovascular risk modification: A systematic review. Front. Public Health 2015, 3, 69. [CrossRef]

50. DeFronzo, R.A.; Ferrannini, E.; Groop, L.; Henry, R.R.; Herman, W.H.; Holst, J.J.; Hu, F.B.; Kahn, R.C.; Raz, I.; Shulman, G.I.; et al. Type 2 diabetes mellitus. Nat. Rev. Dis. Prim. 2015, 1, 1-23. [CrossRef] 
51. Muller, D.C.; Elahi, D.; Tobin, J.D.; Andres, R. Insulin response during the oral glucose tolerance test: The role of age, sex, body fat and the pattern of fat distribution. Aging Clin. Exp. Res. 1996, 8, 13-21. [CrossRef]

52. DeFronzo, R.A. Insulin resistance, lipotoxicity, type 2 diabetes and atherosclerosis: The missing links. Diabetologia 2010, 53, 1270-1287. [CrossRef]

53. Bensellam, M.; Laybutt, D.R.; Jonas, J.C. The molecular mechanisms of pancreatic $\beta$-cell glucotoxicity: Recent findings and future research directions. Mol. Cell. Endocrinol. 2012, 364, 1-27. [CrossRef]

54. Collins, S.; Pi, J.; Yehuda-Shnaidman, E. Uncoupling and reactive oxygen species [ROS]—A double-edged sword for $\beta$-cell function? "Moderation in all things". Best Pract. Res. Clin. Endocrinol. Metab. 2012, 26, 753-758. [CrossRef]

55. Defronzo, R.A. From the triumvirate to the ominous octet: A new paradigm for the treatment of type 2 diabetes mellitus. Diabetes 2009, 58, 773-795. [CrossRef]

56. Odegaard, J.I.; Chawla, A. Pleiotropic actions of insulin resistance and inflammation in metabolic homeostasis. Science 2013, 339, 172-177. [CrossRef] [PubMed]

57. Schellenberg, E.S.; Dryden, D.M.; Vandermeer, B.; Ha, C.; Korownyk, C. Lifestyle interventions for patients with and at risk for type 2 diabetes: A systematic review and meta-analysis. Ann. Intern. Med. 2013, 159, 543-551. [CrossRef] [PubMed]

58. Bendall, C.L.; Mayr, H.L.; Opie, R.S.; Bes-Rastrollo, M.; Itsiopoulos, C.; Thomas, C.J. Central obesity and the Mediterraneandiet: A systematic review of intervention trials. Crit. Rev. Food Sci. Nutr. 2018, 58, 3070-3084. [CrossRef] [PubMed]

59. Mancini, J.G.; Filion, K.B.; Atallah, R.; Eisenberg, M.J. Systematic Review of the MediterraneanDiet for Long-Term Weight Loss. Am. J. Med. 2016, 129, 407-415. [CrossRef] [PubMed]

60. Giammarioli, S.; Filesi, C.; Vitale, B.; Cantagallo, A.; Dragoni, F.; Sanzini, E. Effect of high intakes of fruit and vegetables on redox status in type 2 onset diabetes: A pilot study. Int. J. Vitam. Nutr. Res. 2004, 74, 313-320. [CrossRef] [PubMed]

61. Itsiopoulos, C.; Brazionis, L.; Kaimakamis, M.; Cameron, M.; Best, J.D.; O’Dea, K.; Rowley, K. Can the Mediterraneandiet lower HbA1c in type 2 diabetes? Results from a randomized cross-over study. Nutr. Metab. Cardiovasc. Dis. 2011, 21, 740-747. [CrossRef]

62. Zamora-Ros, R.; Serafini, M.; Estruch, R.; Lamuela-Raventós, R.M.; Martínez-González, M.A.; Salas-Salvadó, J.; Fiol, M.; Lapetra, J.; Arós, F.; Covas, M.I.; et al. Mediterraneandiet and non enzymatic antioxidant capacity in the PREDIMED study: Evidence for a mechanism of antioxidant tuning. Nutr. Metab. Cardiovasc. Dis. 2013, 23, 1167-1174. [CrossRef]

63. Maiorino, M.I.; Bellastella, G.; Petrizzo, M.; Scappaticcio, L.; Giugliano, D.; Esposito, K. Mediterraneandiet cools down the inflammatory milieu in type 2 diabetes: The MÉDITA randomized controlled trial. Endocrine 2016, 54, 634-641. [CrossRef]

64. Eid, H.M.; Martineau, L.C.; Saleem, A.; Muhammad, A.; Vallerand, D.; Benhaddou-Andaloussi, A.; Nistor, L.; Afshar, A.; Arnason, J.T.; Haddad, P.S. Stimulation of AMP-activated protein kinase and enhancement of basal glucose uptake in muscle cells by quercetin and quercetin glycosides, active principles of the antidiabetic medicinal plant vaccinium vitis-idaea. Mol. Nutr. Food Res. 2010, 54, 991-1003. [CrossRef]

65. Dhanya, R.; Arya, A.D.; Nisha, P.; Jayamurthy, P. Quercetin, a lead compound against type 2 diabetes ameliorates glucose uptake via AMPK pathway in skeletal muscle cell line. Front. Pharmacol. 2017, 8, 336. [CrossRef]

66. Tuck, K.L.; Hayball, P.J. Major phenolic compounds in olive oil: Metabolism and health effects. J. Nutr. Biochem. 2002, 13, 636-644. [CrossRef]

67. Torres-Peña, J.D.; Garcia-Rios, A.; Delgado-Casado, N.; Gomez-Luna, P.; Alcala-Diaz, J.F.; Yubero-Serrano, E.M.; Gomez-Delgado, F.; Leon-Acuña, A.; Lopez-Moreno, J.; Camargo, A.; et al. Mediterraneandiet improves endothelial function in patients with diabetes and prediabetes: A report from the CORDIOPREV study. Atherosclerosis 2018, 269, 50-56. [CrossRef] [PubMed]

68. Berger, M.M.; Delodder, F.; Liaudet, L.; Tozzi, P.; Schlaepfer, J.; Chiolero, R.L.; Tappy, L. Three short perioperative infusions of n-3 PUFAs reduce systemic inflammation induced by cardiopulmonary bypass surgery: A randomized controlled trial. Am. J. Clin. Nutr. 2013, 97, 246-254. [CrossRef] [PubMed]

69. Maedler, K.; Oberholzer, J.; Bucher, P.; Spinas, G.A.; Donath, M.Y. Monounsaturated fatty acids prevent the deleterious effects of palmitate and high glucose on human pancreatic $\beta$-cell turnover and function. Diabetes 2003, 52, 726-733. [CrossRef] 
70. Carpentier, Y.A.; Portois, L.; Malaisse, W.J. n-3 Fatty acids and the metabolic syndrome. Am. J. Clin. Nutr. 2006, 83, 1499S-1504S. [CrossRef]

71. Rojo-Martínez, G.; Esteva, I.; Ruiz de Adana, M.S.; García-Almeida, J.M.; Tinahones, F.; Cardona, F.; Morcillo, S.; García-Escobar, E.; García-Fuentes, E.; Soriguer, F. Dietary fatty acids and insulin secretion: A population-based study. Eur. J. Clin. Nutr. 2006, 60, 1195-1200. [CrossRef]

72. Mirabelli, M.; Chiefari, E.; Arcidiacono, B.; Corigliano, D.M.; Brunetti, F.S.; Maggisano, V.; Russo, D.; Foti, D.P.; Brunetti, A. Mediterraneandiet nutrients to turn the tide against insulin resistance and related diseases. Nutrients 2020, 12, 1066. [CrossRef]

73. Visioli, F.; Poli, A.; Galli, C. Antioxidant and other biological activities of phenols from olives and olive oil. Med. Res. Rev. 2002, 22, 65-75. [CrossRef]

74. Beauchamp, G.K.; Keast, R.S.J.; Morel, D.; Lin, J.; Pika, J.; Han, Q.; Lee, C.H.; Smith, A.B.; Breslin, P.A.S. Ibuprofen-like activity in extra-virgin olive oil. Nature 2005, 437, 45-46. [CrossRef]

75. Oh, D.Y.; Talukdar, S.; Bae, E.J.; Imamura, T.; Morinaga, H.; Fan, W.Q.; Li, P.; Lu, W.J.; Watkins, S.M.; Olefsky, J.M. GPR120 Is an Omega-3 Fatty Acid Receptor Mediating Potent Anti-inflammatory and Insulin-Sensitizing Effects. Cell 2010, 142, 687-698. [CrossRef]

76. Yan, Y.; Jiang, W.; Spinetti, T.; Tardivel, A.; Castillo, R.; Bourquin, C.; Guarda, G.; Tian, Z.; Tschopp, J.; Zhou, R. Omega-3 Fatty Acids Prevent Inflammation and Metabolic Disorder through Inhibition of NLRP3 Inflammasome Activation. Immunity 2013, 38, 1154-1163. [CrossRef] [PubMed]

77. Ceriello, A.; Esposito, K.; Sala, L.L.; Pujadas, G.; De Nigris, V.; Testa, R.; Bucciarelli, L.; Rondinelli, M.; Genovese, $\mathrm{S}$. The protective effect of the Mediterraneandiet on endothelial resistance to GLP-1 in type 2 diabetes: A preliminary report. Cardiovasc. Diabetol. 2014, 13, 1-9. [CrossRef] [PubMed]

78. Nyström, T.; Gutniak, M.K.; Zhang, Q.; Zhang, F.; Holst, J.J.; Ahrén, B.; Sjöholm, Å. Effects of glucagon-like peptide- 1 on endothelial function in type 2 diabetes patients with stable coronary artery disease. Am. J. Physiol. Endocrinol. Metab. 2004, 287, E1209-E1215. [CrossRef] [PubMed]

79. Ceriello, A.; Esposito, K.; Testa, R.; Bonfigli, A.R.; Marra, M.; Giugliano, D. The possible protective role of glucagon-like peptide1 on endothelium during the meal and evidence for an "endothelial resistance" to glucagon-like peptide 1 in diabetes. Diabetes Care 2011, 34, 697-702. [CrossRef] [PubMed]

80. Oeseburg, H.; De Boer, R.A.; Buikema, H.; Van Der Harst, P.; Van Gilst, W.H.; Silljé, H.H.W. Glucagon-like peptide 1 prevents reactive oxygen species-induced endothelial cell senescence through the activation of protein kinase a. Arterioscler. Thromb. Vasc. Biol. 2010, 30, 1407-1414. [CrossRef] [PubMed]

81. Sundström, L.; Myhre, S.; Sundqvist, M.; Ahnmark, A.; McCoull, W.; Raubo, P.; Groombridge, S.D.; Polla, M.; Nyström, A.C.; Kristensson, L.; et al. The acute glucose lowering effect of specific GPR120 activation in mice is mainly driven by glucagon-like peptide 1. PLoS ONE 2017, 12, e0189060. [CrossRef]

82. Holst, J.J. The physiology of glucagon-like peptide 1. Physiol. Rev. 2007, 87, 1409-1439. [CrossRef]

83. Nie, C.; He, T.; Zhang, W.; Zhang, G.; Ma, X. Branched Chain Amino Acids: Beyond Nutrition Metabolism. Int. J. Mol. Sci. 2018, 19, 954. [CrossRef]

84. Guasch-Ferré, M.; Hruby, A.; Toledo, E.; Clish, C.B.; Martínez-González, M.A.; Salas-Salvadó, J.; Hu, F.B. Metabolomics in prediabetes and diabetes: A systematic review and meta-analysis. Diabetes Care 2016, 39, 833-846. [CrossRef]

85. Tremblay, F.; Krebs, M.; Dombrowski, L.; Brehm, A.; Bernroider, E.; Roth, E.; Nowotny, P.; Waldhäusl, W.; Marette, A.; Roden, M. Overactivation of S6 kinase 1 as a cause of human insulin resistance during increased amino acid availability. Diabetes 2005, 54, 2674-2684. [CrossRef]

86. Zhenyukh, O.; Civantos, E.; Ruiz-Ortega, M.; Sánchez, M.S.; Vázquez, C.; Peiró, C.; Egido, J.; Mas, S. High concentration of branched-chain amino acids promotes oxidative stress, inflammation and migration of human peripheral blood mononuclear cells via mTORC1 activation. Free Radic. Biol. Med. 2017, 104, 165-177. [CrossRef]

87. Ruiz-Canela, M.; Guasch-Ferré, M.; Toledo, E.; Clish, C.B.; Razquin, C.; Liang, L.; Wang, D.D.; Corella, D.; Estruch, R.; Hernaez, A.; et al. Plasma branched chain/aromatic amino acids, enriched Mediterraneandiet and risk of type 2 diabetes: Case-cohort study within the PREDIMED Trial. Diabetologia 2018, 61, 1560-1571. [CrossRef] [PubMed]

88. Nicholson, J.K.; Holmes, E.; Kinross, J.; Burcelin, R.; Gibson, G.; Jia, W.; Pettersson, S. Host-gut microbiota metabolic interactions. Am. Assoc. Adv. Sci. 2012, 336, 1262-1267. [CrossRef] [PubMed] 
89. Blandino, G.; Inturri, R.; Lazzara, F.; Di Rosa, M.; Malaguarnera, L. Impact of gut microbiota on diabetes mellitus. Diabetes Metab. 2016, 42, 303-315. [CrossRef] [PubMed]

90. Larsen, N.; Vogensen, F.K.; Van Den Berg, F.W.J.; Nielsen, D.S.; Andreasen, A.S.; Pedersen, B.K.; Al-Soud, W.A.; Sørensen, S.J.; Hansen, L.H.; Jakobsen, M. Gut microbiota in human adults with type 2 diabetes differs from non-diabetic adults. PLoS ONE 2010, 5, e9085. [CrossRef]

91. Karlsson, F.H.; Tremaroli, V.; Nookaew, I.; Bergström, G.; Behre, C.J.; Fagerberg, B.; Nielsen, J.; Bäckhed, F. Gut metagenome in European women with normal, impaired and diabetic glucose control. Nature 2013, 498, 99-103. [CrossRef] [PubMed]

92. Sato, J.; Kanazawa, A.; Ikeda, F.; Yoshihara, T.; Goto, H.; Abe, H.; Komiya, K.; Kawaguchi, M.; Shimizu, T.; Ogihara, T.; et al. Gut dysbiosis and detection of "Live gut bacteria" in blood of Japanese patients with type 2 diabetes. Diabetes Care 2014, 37, 2343-2350. [CrossRef] [PubMed]

93. Wang, J.; Qin, J.; Li, Y.; Cai, Z.; Li, S.; Zhu, J.; Qin, J.; Li, Y.; Cai, Z.; Li, S.; et al. A metagenome-wide association study of gut microbiota in type 2 diabetes. Nature 2012, 490, 55-60.

94. Pedersen, H.K.; Gudmundsdottir, V.; Nielsen, H.B.; Hyotylainen, T.; Nielsen, T.; Jensen, B.A.H.; Pedersen, H.K.; Gudmundsdottir, V.; Nielsen, H.B.; Hyotylainen, T.; et al. Human gut microbes impact host serum metabolome and insulin sensitivity. Nature 2016, 535, 376-381. [CrossRef]

95. Miura, K.; Ohnishi, H. Role of gut microbiota and Toll-like receptors in nonalcoholic fatty liver disease. World J. Gastroenterol. 2014, 20, 7381-7391. [CrossRef]

96. Gomes, J.M.G.; De Assis Costa, J.; Alfenas, R.D.C.G. Metabolic endotoxemia and diabetes mellitus: A systematic review. Metab. Clin. Exp. 2017, 68, 133-144. [CrossRef] [PubMed]

97. Urpi-Sarda, M.; Almanza-Aguilera, E.; Llorach, R.; Vázquez-Fresno, R.; Estruch, R.; Corella, D.; Sorli, J.V.; Carmona, F.; Sanchez-Pla, A.; Salas-Salvadó, J.; et al. Non-targeted metabolomic biomarkers and metabotypes of type 2 diabetes: A cross-sectional study of PREDIMED trial participants. Diabetes Metab. 2019, 45, 167-174. [CrossRef] [PubMed]

98. Zmora, N.; Suez, J.; Elinav, E. You are what you eat: Diet, health and the gut microbiota. Nat. Rev. Gastroenterol. Hepatol. 2019, 16, 35-56. [CrossRef] [PubMed]

99. Gentile, C.L.; Weir, T.L. The gut microbiota at the intersection of diet and human health. Am. Assoc. Adv. Sci. 2018, 362, 776-780. [CrossRef]

100. Haro, C.; Montes-Borrego, M.; Rangel-Zúñiga, O.A.; Alcalã-Diaz, J.F.; Gamez-Delgado, F.; Pérez-Martinez, P.; Delgado-Lista, J.; Quintana-Navarro, G.M.; Tinahones, F.J.; Landa, B.B.; et al. Two healthy diets modulate gut microbial community improving insulin sensitivity in a human obese population. J. Clin. Endocrinol. Metab. 2016, 101, 233-242. [CrossRef] [PubMed]

101. Mandaliya, D.K.; Seshadri, S. Short Chain Fatty Acids, pancreatic dysfunction and type 2 diabetes. Pancreatology 2019, 19, 280-284. [CrossRef]

102. Puddu, A.; Sanguineti, R.; Montecucco, F.; Viviani, G.L. Evidence for the Gut Microbiota Short-Chain Fatty Acids as Key Pathophysiological Molecules Improving Diabetes. Mediat. Inflamm. 2014, 2014, 162021. [CrossRef]

103. Cani, P.; Delzenne, N. The Role of the Gut Microbiota in Energy Metabolism and Metabolic Disease. Curr. Pharm. Des. 2009, 15, 1546-1558. [CrossRef]

104. Zhao, L.; Zhang, F.; Ding, X.; Wu, G.; Lam, Y.Y.; Wang, X.; Fu, H.; Xue, X.; Lu, C.; Ma, J.; et al. Gut bacteria selectively promoted by dietary fibers alleviate type 2 diabetes. Science 2018, 359, 1151-1156. [CrossRef]

105. McCreight, L.J.; Bailey, C.J.; Pearson, E.R. Metformin and the gastrointestinal tract. Diabetologia 2016, 59, 426-435. [CrossRef]

106. Zhu, C.; Sawrey-Kubicek, L.; Beals, E.; Rhodes, C.H.; Houts, H.E.; Sacchi, R.; Zivkovic, A.M. Human gut microbiome composition and tryptophan metabolites were changed differently by fast food and Mediterraneandiet in 4 days: A pilot study. Nutr. Res. 2020, 77, 62-72. [CrossRef] [PubMed]

(C) 2020 by the authors. Licensee MDPI, Basel, Switzerland. This article is an open access article distributed under the terms and conditions of the Creative Commons Attribution (CC BY) license (http://creativecommons.org/licenses/by/4.0/). 